\title{
Studi Skema Pembiayaan Pembangunan Kapal Baru Berbasis Multi Vendor menggunakan Fasilitas KUR (Kredit Usaha Rakyat)
}

\author{
Bambang Kristanto, dan Heri Supomo \\ Departemen Teknik Perkapalan, Fakultas Teknologi Kelautan, Institut Teknologi Sepuluh Nopember \\ (ITS) \\ e-mail: hsupomo@na.its.ac.id
}

\begin{abstract}
Abstrak - Pembangunan sebuah kapal dibutuhkan modal yang sangat besar sehingga dengan adanya kredit KUR diharapkan dapat membantu memberikan solusi modal awal pembiayaan bagi galangan kapal. Dengan metode multi vendor dapat dijadikan salah satu terobosan baru agar dapat memanfaatkan fasilitas KUR untuk pembiayaan pembangunan kapal baru. Tujuan dari penelitian Studi ini adalah untuk melakukan studi penggunaan kredit KUR sebagai modal pembiayaan dalam membangun sebuah kapal. Pertama, dilakukan analisis terhadap sistem pembiayaan yang dilakukan saat ini. Kedua, kebutuhan material yang telah diuraikan di Rencana Anggaran Biaya (RAB) kemudian dibagi ke dalam beberapa vendor/supplier di galangan. Ketiga, penyusunan skema pembiayaan dengan menggunakan fasilitas kredit KUR. Berdasarkan hasil analisis, vendor/supplier yang mempunyai kebutuhan modal melebihi plafon maksimal kredit KUR maka tidak dapat disimulasikan sehingga dihitung menggunakan skema kredit komersial. Hasil simulasi menunjukkan bahwa: Pembiayaan Skema I dengan variasi bunga efektif menunjukkan bahwa vendor mendapatkan keuntungan sebesar $10.828 \%$. Pembiayaan Skema II dengan variasi bunga flat menunjukkan bahwa vendor mendapatkan keuntungan sebesar $10.545 \%$. Pembiayaan Skema III dengan variasi bunga efektif dan angsuran per tiga bulanan didapatkan keuntungan vendor sebesar $\mathbf{1 0 . 6 1 7 \%}$. Pembiayaan Skema IV dengan variasi bunga flat dan angsuran per tiga bulanan didapatkan keuntungan vendor sebesar $10.513 \%$. Sedangkan pembiayaan Skema V dengan variasi perhitungan kredit secara komersial didapatkan keuntungan vendor sebesar $9.879 \%$. Berdasarkan hasil simulasi pembiayaan pembangunan kapal menggunakan fasilitas kredit KUR yang telah dilakukan, pada simulasi pembiayaan Skema I diperoleh keuntungan vendor paling maksimal.
\end{abstract}

Kata Kunci-Kredit Usaha Rakyat, Pembiayaan, Multi vendor, Galangan Kapal.

\section{PENDAHULUAN}

$\mathrm{G}$ ALANGAN merupakan tempat yang digunakan untuk proses pembangunan kapal. Pada proses pembangunan, galangan kapal juga mempunyai beberapa aspek yang harus diawasi, antara lain: man, material, money, methode, and machine. Salah satu yang menjadi point penting dalam menjalankan proses pembangunan kapal baru di galangan yaitu money atau biaya. Apabila galangan tidak mempunyai cukup biaya untuk modal awal dan operasional pembangunan maka proses pembangunan kapal akan terhambat. Oleh sebab itu proses pembiayaan pembangunan kapal memerlukan pengawasan yang sangat teliti. Beberapa masalah pembiayaan yang menjadi penghambat proses pembangunan kapal diantaranya: modal yang dimiliki oleh galangan tidak mencukupi, keterlambatan pembayaran termin owner, serta keterbatasan aset galangan yang dimiliki sehingga plafon kredit tidak sebanding dengan jaminan yang diberikan.

Kaitannya dengan proses pembiayaan suatu kegiatan usaha. Pemerintah mempunyai program KUR yang telah terlaksana sejak tahun 2007. KUR adalah skema kredit/peminjaman modal kerja dan atau investasi yang khusus diperuntukkan bagi Usaha Mikro Kecil Menengah dan Koperasi (UMKMK) di bidang usaha produktif dan layak, namun mempunyai keterbatasan dalam pemenuhan pinjaman modal. Melalui Program KUR ini suku bunga yang dibebankan kepada kreditur sebesar 9\% efektif pertahun. Dimana besar subsidi bunga pinjaman disesuaikan dengan kesepakatan antara pemerintah dengan pihak bank. Kemudian dengan sistem multi vendor ini dapat dimulai pembangunan kapal baru dengan cara menghimpun peminjaman modal yang telah dilakukan oleh masing-masing vendor melalui program KUR. Walaupun plafon program KUR terbatas, apabila galangan mampu menghimpun vendor-vendor di bawahnya maka potensi pembiayaan pembangunan kapal menggunakan fasilitas KUR dapat diaplikasikan.

\section{STUDI PUSTAKA}

\section{A. Proses Produksi Kapal}

Industri perkapalan merupakan suatu proses industri yang menghasilkan produk sebuah alat transportasi berupa kapal, bangunan lepas pantai ataupun peralatan apung lainnya. Biasanya kapal dan peralatan apung lainnya dibuat di sebuah perusahaan industri yang disebut dengan Galangan. Kegiatan utama dalam proses produksi sebuah kapal meliputi beberapa tahapan diantaranya [1]:

- Penyusunan Persyaratan Teknis

- Perancangan Awal/Preliminary Design

- Perancangan Kontrak/Contract Design

- Proses Tender/Kontrak

- Proses Produksi

- Proses Serah Terima Kapal 


\section{B. Pembiayaan Pembangunan Kapal Baru}

Setelah mengetahui perilaku sumber pendanaan dari kapal yang akan dibangun, maka bagi pemilik kapal (owner) atau pemilik investasi perlu melakukan rasionalisasi struktur biaya kapal yang disesuaikan dengan peralatan dan spesifikasi teknis operasional yang diinginkan oleh pemilik kapal. Pada dasarnya terdapat lima bagian dasar yang menjadi pertimbangan penilaian, yaitu [2]:

- Konstruksi badan kapal

- Peralatan-peralatan kapal

- Peralatan geladak

- Sistem penggerak kapal

- $\quad$ Sistem permesinan bantu

Sistem dan struktur pembiayaan pada pembangunan kapal baru pun dilakukan berdasarkan kelima elemen bagian utama kapal tersebut di atas.

\section{Kredit}

\section{- Pengertian Kredit}

Kata kredit kerasal dari bahasa Latin credere yang berarti percaya atau to believe/to trust. Oleh karena itu Dasar persetujuan pemberian kredit oleh suatu lembaga keuangan atau perbankan kepada seseorang atau badan usaha berlandaskan asas kepercayaan. Bila dikaitkan dengan kegiatan usaha, kredit berarti suatu kegiatan yang memberikan nilai ekonomi (economic value) kepada seseorang atau suatu badan usaha berlandaskan asas kepercayaan, bahwa nilai ekonomi akan dikembalikan sejumlah nilai ekonomi yang sama dalam jangka waktu tertentu kepada kreditur bank sesuai kesepakatan perjanjian antara kreditur (bank) dengan debitur (user) [3].

Menurut Undang-undang Perbankan no. 10 tahun 1998, yang dimaksud dengan kredit adalah penyediaan uang atau tagihan yang dapat dipersamakan dengan itu, berdasarkan persetujuan atau kesepakatan pinjam meminjam antara bank dengan pihak lain yang mewajibkan pihak peminjam melunasi hutangnya setelah jangka waktu tertentu dengan pemberian bunga.

\section{- Klasifikasi Kredit}

Jika pengusaha melakukan pengklasifikasian dalam membagi suatu produknya, sama halnya dengan bank. Bank biasanya juga melakukan pengklasifikasian kredit sesuai dengan jenisnya, sedangkan untuk suatu jenis kredit dapat dilihat dari berbagai sudut seperti berikut [4]:

a. Jangka Waktu Kredit, yang menjadi tolok ukur dari klasifikasi berdasarkan jangka waktu kredit yaitu lamanya kredit yang diberikan debitur kepada pihak kreditur.

b. Sifat Penggunaan Dana, yang menjadi pertimbangan klasifikasi kedua ini yaitu dari segi sifat penggunaan dana kredit yang akan dipakai, apakah prospek untuk diberikan kredit atau tidak.

c. Mata Uang, berdasarkan kriteria ini, dikenal dengan kredit dalam mata uang rupiah dan valuta asing (Dolar Amerika, Dolar Singapura, Euro, dan sebagainya). Di Indonesia, pinjaman dalam mata uang asing kebanyakan didominasi oleh Dolar Amerika. Hal ini oleh karena transaksi internasional masih menggunakan mata uang tersebut.

\section{d. Tujuan Penggunaan dana kredit}

\section{KUR (Kredit Usaha Rakyat)}

Sesuai Pasal 1 Keputusan Menteri Koordinator Bidang Perekonomian Republik Indonesia Nomor 8 Tahun 2015, bahwa yang dimaksud dengan Kredit Usaha Rakyat yang selanjutnya disingkat menjadi KUR adalah kredit/pembiayaan modal kerja dan/atau investasi kepada debitur usaha yang produktif dan layak namun belum memiliki agunan tambahan atau agunan tambahan belum cukup. Instansi yang digunakan sebagai penyalur KUR adalah bank atau lembaga keuangan bukan bank yang ditunjuk sebagai penyalur KUR. Sedangkan dalam proses peminjaman KUR harus adan perusahaan penjamin yang ditunjuk untuk memberikan penjaminan KUR. Yang dimaksud dengan penjaminan adalah kegiatan memberikan jaminan atas pemenuhan kewajiban finansial debitur KUR oleh perusahaan yang memberikan jaminan. Dalam setiap peminjaman tetap ada suku bunga yang dikenakan dalam pemberian KUR.

Kredit Usaha Rakyat (KUR) adalah Kredit Modal Kerja (KMK) dan atau Kredit Investasi (KI) dengan plafon kredit sampai dengan Rp. 500 juta. Di samping itu, terdapat pula KUR Mikro dengan plafon maksimal Rp. 25 juta. Pinjaman ini diberikan kepada usaha mikro, kecil, menengah dan koperasi yang memiliki usaha produktif yang layak (feasible) namun belum bankable. Pinjaman tersebut sebagian dijamin dengan program penjaminan kredit oleh pemerintah melalui PT. Asuransi Kredit Indonesia (Askrindo) dan Perum Jaminan Kredit Indonesia (Jamkrindo).Menurut Tim Nasional Percepatan Penanggulangan Kemiskinan (2016), Kredit Usaha Rakyat (KUR) adalah skema kredit/pembiayaan modal kerja dan atau investasi yang khusus diperuntukkan bagi Usaha Mikro Kecil Menengah dan Koperasi (UMKMK) di bidang usaha produktif dan layak (feasible), namun mempunyai keterbatasan dalam pemenuhan persyaratan yang ditetapkan Perbankan (belum bankable)[5]. Jenis KUR dibagi menjadi beberapa, diantaranya:

- KUR Mikro

- KUR Ritel

- KUR Penempatan TKI

- KUR Linkage Program Channeling

- KUR Linkage Program Executing

\section{E. Vendor}

Vendor atau Supplier adalah lembaga, perorangan atau pihak ketiga yang menyediakan bahan, jasa, produk untuk diolah atau dijual kembali atau dibutuhkan oleh perusahaan untuk meningkatkan kinerja perusahaan. Istilah lainnya, vander atau vendor, bertindak sebagai orang ketiga antara konsumen dan yang meproduksi barang, istilah vendor ini di dalam dunia bisnis lebih tepatnya disebut supplier, suatu PT atau CV yang berbadan hukum mempunyai ijin usaha sebagai penyuply barang-barang atau jasa hingga sampai ketangan para consumen/pelanggan. Vendor bukan yg memproduksi barang atau jasa, tetapi vendor bertanggung jawab menyediakan barang barang dan jasa yang sesuai permintaan konsumen. Kemudian Vendor/Supplier yang bekerja sama dengan galangan kapal sangatlah banyak, beberapa vendor yang berada di galangan kapal diantaranya: Vendor 
Subkontraktor; Vendor Pelat dan Profil; Vendor Pipa; Vendor Perlengkapan Kapal dll.

\section{METODOLOGI PENELITIAN}

\section{A. Studi Literatur dan Studi Lapangan}

Studi Literatur adalah studi teori-teori yang akan digunakan dalam menyelesaikan studi serta untuk lebih memahami permasalahan yang akan dibahas dalam studi ini. Referensi-referensi untuk mengerjakan jurnal ini didapatkan dari buku, jurnal ilmiah, paper, studi sebelumnya yang masih berkaitan, dan browsing dari internet yang kompeten dan dapat dipertanggungjawabkan. Selanjutnya yaitu melakukan studi lapangan apakah teori yang didapatkan mempunyai relevansi sehingga metode studi ini dapat mengarah kepada sinkronisasi berupa problem solving. Dasar teori yang menjadi fokusan untuk ditelaah antara lain:

- Dasar teori pemahaman secara umum tentang kapal dan proses pembangunan kapal baru.

- Dasar teori tentang pembiayaan pembangunan kapal baru

- Mekanisme proses pengajuan kredit KUR kepada lembaga perbankan

- Implementasi panduan proses pengajuan kredit KUR untuk pembiayaan pembangunan kapal baru

\section{B. Pengumpulan Data}

Pengumpulan data disini merupakan data-data yang dijadikan dasar untuk melakukan proses penyusunan skema pembiayaan kapal menggunakan fasilitas program KUR. Datadata yang dibutuhkan dalam jurnal ini antara lain Rencana Anggaran Biaya (RAB) pembangunan kapal baru dan data vendor/supplier material di galangan.

\section{Penyusunan Skema Pembiayaan menggunakan KUR}

Dari data RAB dan vendor yang telah didapatkan, selanjutnya yaitu menyusun skema pembiayaan untuk pembangunan kapal baru menggunakan fasilitas KUR. Dari RAB yang telah didapatkan kemudian membagi vendor sesuai bidang industri yang dijalankan dan membagi plafon kredit sesuai dengan ketentuan KUR. Setelah dilakukan pembagian kepada masing-masing vendor sesuai kebutuhan modalnya kemudian dilakukan simulasi pembiayaan untuk masingmasing vendor.

\section{PEMBIAYAAN PEMBANGUNAN KAPAL BARU SAAT INI}

\section{A. Skema Pembiayaan Awal Galangan}

Skema pembiayaan awal galangan yang dimaksud yaitu modal awal galangan yang akan dipakai dalam memulai proses pembangunan kapal. Modal yang akan dipakai galangan ini didapatkan dari berbagai skema diantaranya:

- Modal Sendiri

- Pinjaman Bank

- Termin Owner

\section{B. Skema Pembayaran Material kepada Vendor}

Pada saat galangan membutuhkan material yang akan dipakai untuk pembangunan kapal. Ada beberapa cara/sistem pembayaran yang saat ini dilakukan galangan kepada vendor/supplier material, diantaranya:

- Pembayaran Cash On Delivery

- Pembayaran Cash Before Delivery

- Termin

- Escrow Account

\section{Skema Pembayaran Owner kepada Galangan}

Dalam proses pembangunan sebuah kapal dibutuhkan dana yang sangat besar sesuai dengan jenis dan besar kapal yang akan dibangun. Sampai saat ini ada beberapa metode atau skema yang dilakukan antara pihak onwer dengan pihak galangan dalam menjalankan proyek pembangunan sebuah kapal. Dengan arti sebelum memulai pembangunan kapal, owner memberikan sejumlah nilai proyek sebagai modal awal dalam memulai pembangunan kapal Beberapa skema yang dilakukan saat ini diantaranya:

- Skema Pembayaran di Awal

- Skema Pembayaran Termin

- Skema Pembayaran Sekaligus di Akhir

\section{Sample Biaya Pembangunan Tug Boat 2x1600 HP}

Sesuai kontrak pembangunan Kapal, pembangunan Kapal Tunda 2x1600 HP dijadwalkan selesai pada tanggal 24 Juni 2015 sejak penandatanganan kontrak pada tanggal 21 Januari 2014. Teknik penjadwalan yang digunakan untuk pembangunan kapal tunda ini dengan metode bharchart (Gant's chart) yaitu berupa grafik chart yang menggambarkan pekerjaan lawan waktu. Ukuran utama dari kapal tunda 2x1600 HP yang akan dibangun dapat dilihat pada Table 1 sebagai berikut:

Tabel 1.

Dimensi Kapal Tunda 2x1600 HP

\begin{tabular}{cc}
\hline \hline ITEM & VALUE \\
\hline Panjang seluruhnya (LOA) tanpa fender (Abt.) & $32.50 \mathrm{~m}$ \\
Panjang antara garis tegak lurus (LBP) (Abt.) & $28.40 \mathrm{~m}$ \\
Lebar (B) (Abt.) & $9.80 \mathrm{~m}$ \\
Tinggi di tengah-tengah kapal (D) (Abt.) & $5.00 \mathrm{~m}$ \\
Desain draught at midship max (max.) & $3.30 \mathrm{~m}$ \\
Height on deckhouse (Abt.) & $2.50 \mathrm{~m}$ \\
Daya mesin induk & $2 \times 1600 \mathrm{HP}$ \\
\hline \hline
\end{tabular}

Nilai Kontrak dan RAB yang akan dijadikan studi kasus dalam penelitian ini yaitu kontrak pembangunan Tug Boat 2x1600 HP. Kapal Tunda ini mulai dibangun pada tahun 2014 dengan nilai kontrak sebesar Rp. 45.388.278.726 . Nilai kontrak tersebut merupakan Rencana Anggaran Biaya (RAB) yang berupa perkiraan besar anggaran biaya yang akan digunakan dari perencanaan, pembangunan sampai pemeliharaan kapal. Dengan menggunakan RAB tersebut galangan dapat memperkirakan besar keuntungan yang akan didapat dengan proyek pembangunan kapal tersebut. Di dalam rencana anggaran biaya pembangunan kapal dibagi dalam dua klasifikasi biaya, yaitu biaya material dan biaya tenaga 
kerja/pekerjaan jasa. Rincian biaya dapat dilihat seperti pada Tabel 2 sebagai berikut:

Tabel 2.

Uraian Biaya Pekerjaan dan material

\begin{tabular}{|c|c|c|c|}
\hline No. & Uraian & $\begin{array}{c}\text { Rencana } \\
\text { Anggaran } \\
\text { Biaya (RAB) }\end{array}$ & $\begin{array}{c}\text { Harga Pokok } \\
\text { Produksi (HPP) }\end{array}$ \\
\hline 1 & Jasa Pekerjaan & $1,590,559,110$ & $1,272,447,288$ \\
\hline 2 & General Expenses & $2,624,593,440$ & $2,099,674,752$ \\
\hline 3 & Lambung & $3,006,155,670$ & $2,404,924,536$ \\
\hline 4 & $\begin{array}{c}\text { Perlengkapan lambung dan } \\
\text { Geladak }\end{array}$ & $5,210,835,651$ & $4,168,668,521$ \\
\hline 5 & $\begin{array}{c}\text { Instalasi Permesinan dan } \\
\text { Perlengkapan kamar Mesin }\end{array}$ & $30,769,947,390$ & $24,615,957,912$ \\
\hline 6 & $\begin{array}{c}\text { Instalasi Listrik dan } \\
\text { perlengkapannya }\end{array}$ & $1,485,669,045$ & $1,188,535,236$ \\
\hline 7 & $\begin{array}{c}\text { Pembersihan, pengecatan \& } \\
\text { perlindungan karat }\end{array}$ & $404,391,750$ & $323,513,400$ \\
\hline \multirow[t]{2}{*}{8} & $\begin{array}{l}\text { Instalasi perpipaan, valve, } \\
\text { flens dan perlengkapan }\end{array}$ & $296,126,670$ & $236,901,336$ \\
\hline & JUMLAH TOTAL & $45,388,278,726$ & $36,310,622,981$ \\
\hline
\end{tabular}

\section{PENYUSUNAN SKEMA PEMBIAYAAN MENGGUNAKAN KUR}

\section{A. Pembagian Vendor Sesuai Material dan Besar Plafon kredit}

Tahap pertama dari penyusunan skema ini yaitu dengan membagi vendor-vendor di galangan sesuai plafon kredit yang disediakan oleh program KUR. Dalam pembagian tahap pertama yang dilakukan adalah dengan membagi material sesuai komoditi material tertentu. Dari hasil pembagian sesuai RAB yang telah dilakukan, komoditi material terbagi menjadi sepuluh kelompok yaitu: Subkontraktor, Pelat dan Profil, Pipa, Outfitting Lambung dan Geladak, Permesinan dan Perlengkapannya, Electric, Painting, Consumable, Konsultan, serta Spesifikasi dan Pengujian. Sebelum membagi material ke dalam vendor-vendor tertentu, dikarenakan RAB yang digunakan sebagai studi kasus dikerjakan pada tahun 2014 maka dapat dihitung terlebih dahulu inflasi yang terjadi dari tahun 2014 sampai saat ini. Selama dua tahun didapatkan ratarata inflasi sebesar 5\%. Maka besar biaya material masingmasing ditambah sebesar 5\% dari biaya material. Untuk lebih jelasnya dapat dilihat seperti pada Tabel 3 sebagai berikut:

Tabel 3.

Besar Biaya Material masing-masing Vendor

\begin{tabular}{|c|c|c|c|}
\hline $\begin{array}{c}\text { Komoditi } \\
\text { Material }\end{array}$ & Vendor/Supplier & RAB (Rp) & HPP (Rp) \\
\hline Subkontraktor & $\begin{array}{l}\text { CV Langgeng } \\
\text { Tehnik }\end{array}$ & $1,670,087,066$ & $1,336,069,652$ \\
\hline \multirow{2}{*}{ Pelat dan profil } & $\begin{array}{l}\text { PT. Gerai Baja } \\
\text { Indonesia }\end{array}$ & $1,423,614,812$ & $1,138,891,849$ \\
\hline & $\begin{array}{l}\text { PT. Sinarindo } \\
\text { Megah Perkasa }\end{array}$ & $1,423,614,812$ & $1,138,891,849$ \\
\hline \multirow[t]{2}{*}{ Pipa } & $\begin{array}{c}\text { PT. Sapta } \\
\text { Sumber Lancar }\end{array}$ & $310,933,004$ & $248,746,403$ \\
\hline & CV Mandiri Jaya & $2,470,449,035$ & $1,976,359,228$ \\
\hline \multirow{2}{*}{$\begin{array}{l}\text { Outfitting } \\
\text { Lambung dan } \\
\text { Geladak }\end{array}$} & UD Sinar Abadi & $1,422,369,979$ & $1,137,895,983$ \\
\hline & $\begin{array}{l}\text { UD Samudra } \\
\text { Jaya }\end{array}$ & $1,578,558,420$ & $1,262,846,736$ \\
\hline \multirow{2}{*}{$\begin{array}{l}\text { Permesinan dan } \\
\text { perlengkapannya }\end{array}$} & $\begin{array}{l}\text { PT. Gemini } \\
\text { Gemilang }\end{array}$ & $23,630,874,750$ & $18,904,699,800$ \\
\hline & PT. Surya Segara & $3,841,667,755$ & $3,073,334,204$ \\
\hline
\end{tabular}

\begin{tabular}{ccc} 
PT. Indomarine & $2,484,475,922$ & $1,987,580,738$ \\
Internusa & & \\
PT. Velasco & $2,351,426,333$ & $1,881,141,066$ \\
Indonesia & & \\
PT. Teknik & & \\
Tadakara & $1,559,952,497$ & $1,247,961,998$ \\
Sumberkarya & & \\
UD Sumber Jaya & $424,611,338$ & $339,689,070$ \\
$\quad$ Paint & $309,233,831$ & $247,387,064$ \\
$\begin{array}{c}\text { PT. Aneka Gas } \\
\text { Industri }\end{array}$ & $870,036,773$ & $696,029,418$ \\
$\begin{array}{c}\text { PT. Konsultan } \\
\text { Perkapalan } \\
\text { PT. Biro }\end{array}$ & & \\
Klasifikasi & $1,885,786,340$ & $1,508,629,072$ \\
Indonesia & & \\
$\quad$ TOTAL & $47,657,692,662$ & $38,126,154,130$ \\
\hline
\end{tabular}

\section{B. Jadwal Pembelian Material dan Pengajuan Kredit}

Sesuai skema yang akan dibuat, terlebih dahulu membuat penjadwalan utama yang meliputi jadwal pengajuan kredit dan jadwal pencairan kredit. Sebelum menentukan jadwal kredit terlebih dahulu mengetahui jadwal pembelian material dan jadwal kedatangan material di galangan. Pada sub bab ini terdiri dari empat penjadwalan yaitu; Jadwal pemesanan material, jadwal kedatangan material di galangan, jadwal pengajuan kredit, serta jadwal pencairan kredit. Pada jadwal pembelian material dapat dijadikan juga sebagai jadwal pencairan kredit, dikarenakan simulasi ini mengambil batasan bahwa saat waktu pembelian material kredit pun sudah cair sehingga dapat digunakan sebagai pembayaran/DP material.

\section{ANALISIS DAN PEMBAHASAN}

\section{A. Pembagian Jenis KUR dan Besar Jangka Waktu Kredit}

Sesuai pembagian biaya material yang telah dilakukan pada bab sebelumnya, maka dapat diketahui jenis KUR yang akan diajukan oleh masing-masing vendor. Masing-masing vendor melakukan peminjaman modal sebesar $20 \%$ dari kebutuhan modal/HPP yang dimiliki oleh setiap vendor. Untuk lebih jelasnya dapat dilihat seperti pada Tabel 4 sebagai berikut:

Tabel 4.

Pembagian Jenis KUR Sesuai Besar Plafon Kredit

\begin{tabular}{|c|c|c|c|c|c|c|}
\hline \multirow[t]{2}{*}{ Vendor } & \multirow{2}{*}{$\begin{array}{c}\text { Besar } \\
\text { Pinjaman } \\
\text { (Rp) }\end{array}$} & \multicolumn{5}{|c|}{$\begin{array}{l}\text { Jenis } \\
\text { Kredit }\end{array}$} \\
\hline & & 1 & 2 & 3 & 4 & 5 \\
\hline CV Langgeng Tehnik & $267,213,930$ & & $\sqrt{ }$ & & & \\
\hline PT. Gerai Baja Indonesia & $227,778,370$ & & $\sqrt{ }$ & & & \\
\hline $\begin{array}{c}\text { PT. Sinarindo Megah } \\
\text { Perkasa }\end{array}$ & $227,778,370$ & & $\sqrt{ }$ & & & \\
\hline PT. Sapta Sumber Lancar & $49,749,281$ & & $\sqrt{ }$ & & & \\
\hline CV Mandiri Jaya & $395,271,846$ & & $\sqrt{ }$ & & & \\
\hline UD Sinar Abadi & $227,579,197$ & & $\sqrt{ }$ & & & \\
\hline UD Samudra Jaya & $252,569,347$ & & $\sqrt{ }$ & & & \\
\hline PT. Gemini Gemilang & $3,780,939,960$ & & & & & $\sqrt{ }$ \\
\hline PT. Surya Segara & $614,666,841$ & & & $\sqrt{ }$ & & \\
\hline PT. Indomarine Internusa & $397,516,148$ & & $\sqrt{ }$ & & & \\
\hline PT. Velasco Indonesia & $376,228,213$ & & $\sqrt{ }$ & & & \\
\hline $\begin{array}{l}\text { PT. Teknik Tadakara } \\
\text { Sumberkarya }\end{array}$ & $249,592,400$ & & $\sqrt{ }$ & & & \\
\hline UD Sumber Jaya Paint & $67,937,814$ & & $\sqrt{ }$ & & & \\
\hline PT. Aneka Gas Industri & $49,477,413$ & & $\sqrt{ }$ & & & \\
\hline
\end{tabular}




\begin{tabular}{ccc}
$\begin{array}{c}\text { PT. Konsultan Perkapalan } \\
\text { PT. Biro Klasifikasi } \\
\text { Indonesia }\end{array}$ & $139,205,884$ & $\sqrt{ }$ \\
\hline \hline
\end{tabular}

Keterengan :

$$
\begin{array}{ll}
1 & =\text { KUR Mikro } \\
2 & =\text { KUR Ritel } \\
3 & =\text { KUR Linkage Program (Executing) } \\
4 & =\text { KUR Linkage Program (Channeling) }
\end{array}
$$

\section{B. Besar Keuntungan dari Simulasi Skema Pembiayaan}

Pada bab analisis keuntungan vendor ini akan dijelaskan mengenai besar keuntungan yang didapatkan oleh masingmasng vendor berdasarkan variasi skema-skema pembiayaan yang telah disimulasikan. Kauntungan vendor didapatkan dari sisa jumlah kas akhir yang dimiliki oleh setiap vendor. Salah satu contoh keuntungan vendor dari Skema I dapat dilihat seperti pada Tabel 5 sebagai berikut:

Tabel 5.

Besar Keuntungan tiap Vendor

\begin{tabular}{cr}
\hline \hline Vendor/Supplier & Kas Akhir (Rp) \\
\hline CV Langgeng Tehnik & $194,171,893$ \\
PT. Gerai Baja Indonesia & $164,858,999$ \\
PT. Sinarindo Megah Perkasa & $164,858,999$ \\
PT. Sapta Sumber Lancar & $36,007,004$ \\
CV Mandiri Jaya & $286,085,640$ \\
UD Sinar Abadi & $164,714,843$ \\
UD Samudra Jaya & $182,801,948$ \\
PT. Gemini Gemilang* & $2,381,992,175$ \\
PT. Surya Segara & $439,896,569$ \\
PT. Indomarine Internusa & $287,709,997$ \\
PT. Velasco Indonesia & $272,302,443$ \\
PT. Teknik Tadakara Sumberkarya & $180,647,325$ \\
UD Sumber Jaya Paint & $49,171,306$ \\
PT. Aneka Gas Industri & $35,810,234$ \\
PT. Konsultan Perkapalan & $100,752,950$ \\
PT. Biro Klasifikasi Indonesia & $218,379,891$ \\
TOTAL & $5,160,162,216$ \\
\hline \hline
\end{tabular}

Dari Tabel 5 di atas, dapat diketahui besar keseluruhan keuntungan dari simulasi Skema I yang dimiliki oleh masingmasing vendor dengan total akumulasi sebesar 5,160,162,216 rupiah atau sebesar $\mathbf{1 0 . 8 2 8 \%}$ dari besar RAB. Untuk akumulasi total keuntungan yang didapatkan oleh vendor dari masing-masing variasi skema pembiayaan I sampai $\mathrm{V}$ yang telah dilakukan dapat dilihat seperti pada Tabel berikut

$$
\text { Tabel } 6 .
$$

Perbandingan Keuntungan dari beberapa variasi

\begin{tabular}{ccc}
\hline \hline Skema & Besar Keuntungan (\%) & Besar Keuntungan (Rp) \\
\hline Skema 1 & 10.828 & $5,160,162,216$ \\
Skema 2 & 10.545 & $5,025,590,950$ \\
Skema 3 & 10.617 & $5,060,046,005$ \\
Skema 4 & 10.513 & $5,010,456,575$ \\
Skema 5 & 9.879 & $4,707,874,588$ \\
\hline \hline
\end{tabular}

Dari Tabel 6 dapat diketahui besar akumulasi keuntungan vendor yang didapatkan dari beberapa variasi pembiayaan yang telah disimulasikan. Dari Skema I didapatkan keuntungan sebesar $10.828 \%$ atau sebesar 5,160,162,216 rupiah, Skema II didapatkan keuntungan sebesar $10.545 \%$ atau sebesar 5,025,590,950 rupiah, Skema III didapatkan keuntungan sebesar $10.617 \%$ atau sebesar 5,060,046,005 rupiah, Skema IV didapatkan keuntungan sebesar $10.513 \%$ atau sebesar 5,010,456,575 rupiah, Skema I didapatkan keuntungan sebesar $9.879 \%$ atau sebesar 4,707,874,588 rupiah.

\section{Mekanisme Pengajuan KUR}

Pada sub bab ini akan dijelaskan mengenai mekanisme pengajuan kredit yang harus dilakukan oleh masing masing vendor. Mekanisme pengajuan kredit yang dibuat yaitu disesuaikan dengan jenis kredit KUR yang akan diajukan oleh masing-masing vendor, diantaranya:

- KUR secara langsung

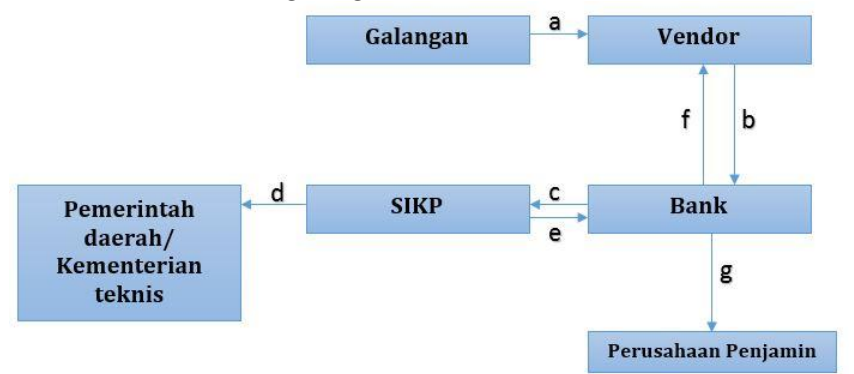

Gambar 1. Mekanisme KUR secara langsung

Keterangan:

$\mathrm{a}=$ Galangan memberikan sejumlah proyek kepada vendor dalam hal supply material

$\mathrm{b}=$ Vendor melakukan pinjaman kredit KUR secara langsung kepada Bank pelaksana

$\mathrm{c}=$ Bank pelaksana meng-upload data calon penerima KUR yang diberikan oleh calon penerima KUR ke Sistem Informasi Kredit Program.

$\mathrm{d}=$ Kementerian/lembaga teknis dan/atau Pemerintah Daerah dapat melakukan identifikasi data calon penerima KUR di sektor dan/atau wilayah masingmasing yang diajukan oleh Lembaga Linkage yang diupload oleh Bank pelaksana dan perusahaan penjamin namun tidak mempengaruhi proses penyaluran KUR.

$\mathrm{e}=$ Bank pelaksana memproses kelayakan kredit/pembiayaan awal.

$\mathrm{f}=$ Bank pelaksana menyalurkan Kredit/Pembiayaan kepada vendor yang memenuhi persyaratan kelayakan kredit oleh Bank.

$\mathrm{g}=$ Bank pelaksana mengajukan permohonan penerbitan Sertifikat Penjaminan atas penyaluran kredit/pembiayaan kepada perusahaan penjamin. Perusahaan Penjamin menerbitkan Sertifikat Penjaminan atas penerima KUR yang telah diberikan oleh Bank pelaksana. 
- $\quad$ KUR Linkage Program (Executing)

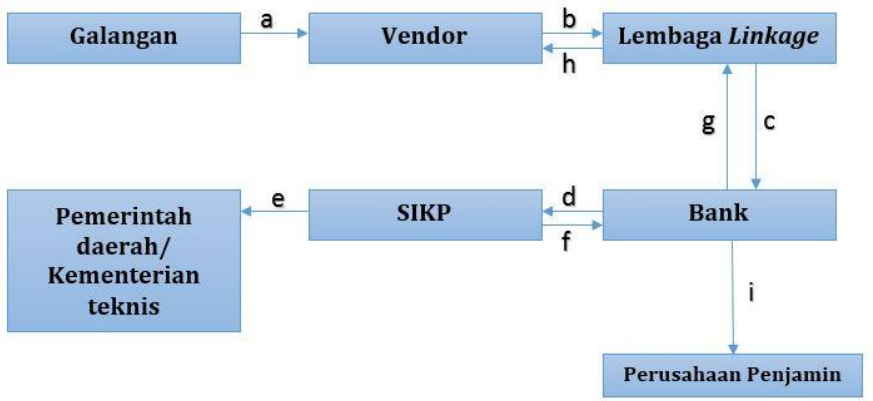

Gambar 2. Mekanisme KUR Linkage Program Executing

Keterangan:

$\mathrm{a}=$ Galangan memberikan sejumlah proyek kepada vendor dalam hal supply material

$\mathrm{b}=$ Vendor melakukan pinjaman kredit KUR melalui lembaga linkage

$\mathrm{c}=$ Lembaga linkage mewakili calon penerima KUR mengajukan permohonan kredit/pembiayaan kepada Bank pelaksana

$\mathrm{d}=$ Bank pelaksana meng-upload data calon penerima KUR yang diberikan oleh Lembaga Linkage ke Sistem Informasi Kredit Program.

$\mathrm{e}=$ Kementerian/lembaga teknis dan/atau Pemerintah Daerah dapat melakukan identifikasi data calon penerima KUR di sektor dan/atau wilayah masingmasing yang diajukan oleh Lembaga Linkage yang diupload oleh bank pelaksana dan perusahaan penjamin namun tidak mempengaruhi proses penyaluran KUR.

$\mathrm{f}=$ Bank pelaksana memproses kelayakan kredit/pembiayaan awal.

$\mathrm{g}=$ Bank pelaksana menyalurkan Kredit/Pembiayaan kepada Lembaga Linkage yang memenuhi persyaratan kelayakan kredit oleh Bank pelaksana.

$\mathrm{h}=$ Lembaga linkage menyalurkan kredit/pembiayaan yang diterima dari Bank pelaksana berdasarkan daftar calon penerima KUR potensialnya.

$\mathrm{i}=$ Bank mengajukan permohonan penerbitan Sertifikat Penjaminan atas penyaluran kredit/pembiayaan kepada Lembaga linkage. Perusahaan Penjamin menerbitkan Sertifikat Penjaminan atas penerima KUR yang telah diberikan oleh bank pelaksana.

- Kredit Komersil

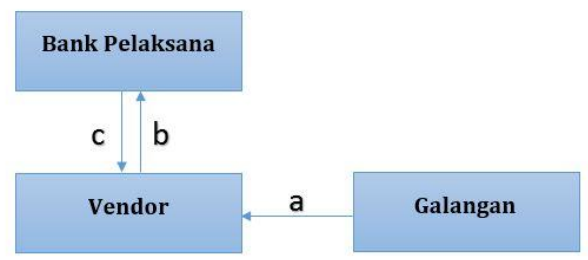

Gambar 3. Mekanisme Kredit Komersil

Keterangan:

$\mathrm{a}=$ Galangan memberikan sejumlah proyek kepada vendor untuk dapat mengajukan peminjaman modal kepada bank;

$\mathrm{b}=$ Vendor secara langsung mengajukan program kredit KMK terhadap Bank Pelaksana;

$\mathrm{c}=$ Kemudian Bank melakukan penilaian secara individu terhadap calon debitur. Apabila dinilai layak dan disetujui oleh Bank Pelaksana, maka vendor menandatangani Perjanjian Kredit.

\section{KESIMPULAN/RINGKASAN}

Setelah dilakukan studi pembiayaan pembangunan kapal baru menggunakan fasilitas KUR, maka kesimpulan dari Studi ini adalah:

1. Sesuai analisis yang telah dilakukan pada bab sebelumnya. Kondisi pembiayaan pembangunan kapal baru saat ini yaitu galangan rata-rata masih mengandalkan pembayaran termin owner sebagai modal dalam pembiayaan pembangunan kapal.

2. Skema yang dibuat pada penelitian ini yaitu pembiayaan kapal berbasis multi vendor. Jadi RAB yang dikeluarkan oleh pihak galangan selanjutnya akan dipecah menjadi beberapa vendor/supplier di bawahnyaBerdasarkan hasil simulasi pembiayaan pembangunan kapal menggunakan fasilitas kredit KUR yang telah dilakukan, pada simulasi pembiayaan Skema I diperoleh keuntungan vendor paling maksimal.

3. Strategi yang dapat diterapkan oleh masing-masing vendor untuk dapat memanfaatkan fasilitas KUR ini yang pertama adalah menyesuaikan besar plafon pinjaman sesuai ketentuan KUR. Selisih bunga antara kredit KUR dengan kredit komersil sebesar 3-4\%. Dimana bunga yang dibebankan pada program KUR lebih kecil dikarenakan adanya subsidi bunga dari pemerintah.

\section{DAFTAR PUSTAKA}

[1] S. Widjaja, "Manajemen Produksi Untuk Industri Perkapalan," ITS, 1996.

[2] S. Gurning, "Aplikasi Pendanaan Kapal," Scribd, 2011. [Online]. Available: https://www.scribd.com/doc/67410448/StrukturPembiayaan-Kapal-Baru.

[3] J. Jusuf, Kiat Jitu Memperoleh Kredit Bank. Jakarta: Gramedia Pustaka, 2003.

[4] M. Tjoekam, Perkreditan Bisnis Inti Bank Komersial. Jakarta: Gramedia Pustaka, 1999.

[5] T. P. UMKM, Buku Kumpulan Peraturan KUR Tahun 2016. Jakarta: Kementerian Perekonomian RI, 2016. 